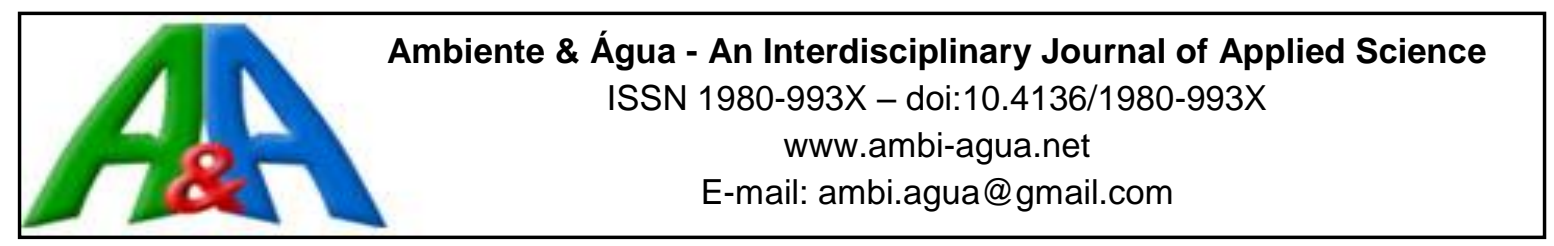

\title{
Household food-waste composting using a small-scale composter
}

\author{
doi:10.4136/ambi-agua.1908 \\ Received: 01 Apr. 2016; Accepted: 21 Jun. 2017 \\ Daniele Vital Vich*; Hitomi Pires Miyamoto; \\ Luciano Matos Queiroz; Viviana Maria Zanta \\ Universidade Federal da Bahia (UFBA), Salvador, BA, Brasil \\ Departamento de Engenharia Ambiental \\ *Corresponding author: e-mail: danielevich@gmail.com, \\ hitomiyamoto@hotmail.com, lmqueiroz@ufba.br, zanta@ufba.br
}

\begin{abstract}
Household food-waste composting is an attractive alternative for Brazilian waste management; however, there are few programs or studies regarding the implementation or management of this small-scale process. This study investigates the performance of food-waste composting using a simple and small-scale domestic composter. Three composting trials were conducted using food waste and wood chips in $10 \mathrm{~L}$ plastic bins using different filling schemes. In the first trial, the composter was filled weekly over two months. In the second, the composter was filled once with a mixture of food waste and $100 \%$ of the used wood chips from the previous trial. In the last third trial, the composter was filled with food waste and wood chips (50\% of wood chips used in the second trial and 50\% of untreated wood chips). The physical chemical parameters of the compost were monitored and the total coliforms and $E$. coli were measured. In all trials, the temperature varied between $26.7^{\circ} \mathrm{C}$ and $46.2^{\circ} \mathrm{C}$ throughout the process. The reduction in wet mass was $58-69 \%$, while the reduction in dry mass was $37-61 \%$. The $\mathrm{pH}$ value, the contents of carbon and nitrogen and the $\mathrm{C} / \mathrm{N}$ ratio were in accordance with the values recommended in norm 25 (July, 2009) adopted by Brazil's Agriculture Ministry. Only the compost from Trial 2, which had $1900 \mathrm{MPN} \mathrm{g}^{-1}$ total solids, did not meet the E. coli standards; this was likely due to the fact that when the temperatures did not reach the thermophilic phase, the relatively long time the waste remains in the composter allows these pathogenic microorganisms to decay naturally.
\end{abstract}

Keywords: domestic composter, food waste, household composting.

\section{Compostagem doméstica de resíduos de alimentos em composteira de pequena escala}

\section{RESUMO}

A compostagem doméstica de resíduos alimentares é uma opção atraente para a gestão dos resíduos no Brasil; no entanto, existem apenas poucos programas, estudos e experiências sobre o comportamento deste processo em pequena escala. Esta pesquisa investigou o desempenho da compostagem de resíduos de alimentos em uma composteira simples e de pequena escala doméstica. Três ensaios de compostagem foram realizados com resíduos de alimentos e aparas de madeira em recipientes de plástico de $10 \mathrm{~L}$ utilizando diferentes estratégias de preenchimento. No primeiro ensaio, a composteira foi preenchida 
semanalmente durante dois meses. No segundo ensaio, a composteira foi preenchida uma única vez com uma mistura de resíduos de alimento e das aparas de madeira utilizadas no ensaio anterior. No último ensaio, a composteira foi preenchida com resíduos de alimentos e aparas de madeiras (50\% de aparas de madeira utilizados na segunda etapa e 50\% de aparas de madeira não tratadas). Os parâmetros físicos e químicos foram monitorados e os coliformes totais e $E$. coli foram quantificados no composto. Em todos os ensaios, a temperatura variou entre $26,7^{\circ} \mathrm{C}$ e $46,2^{\circ} \mathrm{C}$ ao longo do processo. A redução da massa úmida foi de $58-69 \%$, enquanto que a redução da massa seca foi de $37-61 \%$. O valor de $\mathrm{pH}$, os teores de carbono e nitrogênio e a relação $\mathrm{C} / \mathrm{N}$ estavam de acordo com os valores recomendados na instrução normativa 25 (Julho, 2009) do Ministério da Agricultura, Pecuária e Abastecimento. Apenas o composto final do ensaio 2 não correspondeu aos padrões para contagem de $E$. coli, com 1900 NMP g ${ }^{-1}$ sólidos totais. Quando as temperaturas não atingem a faixa termofílica, o tempo relativamente longo em que o resíduo permanece na composteira permite que esses micro-organismos patogênicos decaiam naturalmente.

Palavras-chave: compostagem doméstica, composteira doméstica, resíduos de alimentos.

\section{INTRODUCTION}

Brazilian households, small commercial enterprises and cleaning services produce nearly 94,335 ton day $^{-1}$ of organic waste, which represents $51 \%$ of the municipal solid waste produced (Brasil, 2012). Only 1\% of this waste is destined for composting systems, while $59 \%$ is disposed of in landfills and 39\% is dumped. The National Solid Waste Policy (Brasil, 2010) has zero-waste guidelines for waste, recycling, composting, incineration and end-of-life disposal in landfills. The National Plan of Solid Waste prioritizes composting as an alternative for organic waste management (Brasil, 2012).

The few composting systems in operation in Brazil are mostly open-air, centralized and at a municipal scale. There are few programs or studies regarding household composting. Composting has advantages over incineration and disposal in landfills due to lower operating costs, reduced environmental pollution and, more importantly, the beneficial use of the final product, which can be used as a soil conditioner or fertilizer (Li et al., 2013).

Approximately $90 \%$ of Brazilian municipalities have a population of up to 50,000 inhabitants and the possibility exists of building houses within an area that allows the use of home composting and the use of onsite composting as a fertilizer or in nearby agricultural areas. There are also Brazilian regions in semi-arid climates with poor soil nutrients where the compound could be used as a soil conditioner. Further, there are highly populated urban areas where the practice of home composting and its application in nearby places, such as squares and parks, could reduce the cost of transporting solid waste to landfills. Therefore, adopting home composting systems in Brazil is very attractive.

Composting is the decomposition and stabilization of the organic fraction of solid waste, accomplished by microbes under controlled aerobic conditions. The most important variables in the composting process are a carbon to nitrogen ratio between 20 and 40, moisture content between $50 \%$ and $70 \%$, proper aeration, small particle size and adequate mass transfer between air and solids (Chang et al., 2006). It is evident that the success of household composting depends on the performance of the home composter and on the quality of the product, and experiments have been performed that take into consideration the performance of the domestic composter in relation to passive and/or forced aeration and batch and/or semicontinuous feeding (Chang et al., 2006; Karnchanawong and Suriyanon, 2011).

Several small to medium sized composters (10-300 L) have been developed and their characteristics have influenced the process. In this work, an exploratory study was conducted 
to investigate the performance of food waste composting using a small-scale domestic composter in semi-continuous and batch fill scenarios with new and reused wood chips. Several investigations on home composting have been conducted over the past decade with a focus on the process efficiency regarding different structural materials and operating strategies (Faverial and Sierra, 2014; Lleó et al., 2013; Colón et al., 2010; Chang et al., 2006); the effects of aeration (Karnchanawong and Suriyanon, 2011); the mass balance and life cycle analysis (Andersen et al., 2011); the quality and stability of the compound (Barrena et al., 2014); and gas emissions (Ermolaev et al., 2014; Quirós et al.; 2014).

Most of the research efforts cited have utilized laboratory scale bench or medium-sized composters designed to be installed in backyards and operated with food waste and waste pruning. However, these systems cannot be installed in some houses due to the lack of physical space or green waste from gardening. Therefore, this study evaluated the operation strategies and the efficiency of the waste-composting process by feeding small household composters (10 litres) that could be installed in any environment. In various trials, composters were filled in batch and semi-continuous composting systems. Wood chips (used as a structural material) were inserted in natura or reinserted following the composting cycle to improve aeration and moisture control.

\section{MATERIALS AND METHODS}

\subsection{Experimental apparatus}

Small, low-cost (\$7) plastic bins (total volume of 10 litres) that are widely available in supermarkets were used in this study to make domestic compost (Figure 1). In order to facilitate natural aeration and the drainage of possible leachate during the composting process, $0.6 \mathrm{~cm}$ diameter holes were drilled in the sides of the compost bins, corresponding to $4 \%$ of the surface area.

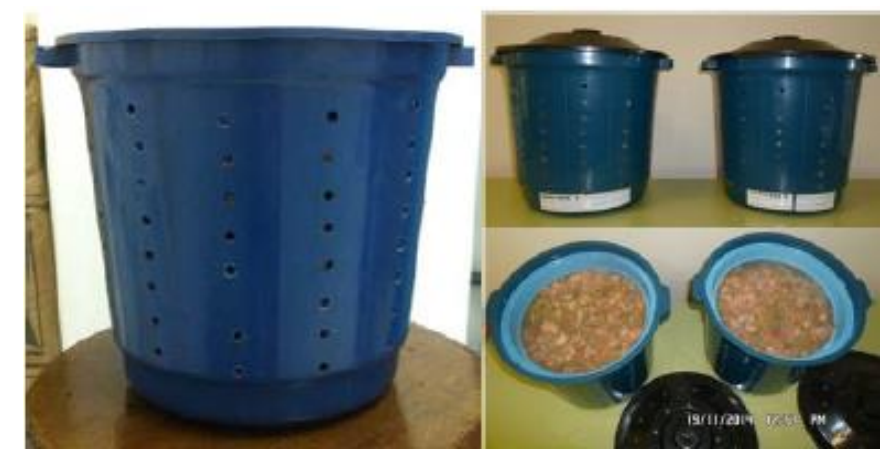

Figure 1. Plastic compost bins used in this study.

\subsection{Composting materials and composter operation}

Food waste from meal preparation and eucalyptus wood chips were properly characterized (Table 1) and used in the experiment. The composting operation was divided into three trials; in each trial, food waste, composed exclusively of vegetables and fruits, was collected from small restaurants. The food-residue size was manually reduced to $1.0 \mathrm{~cm}$ particles and manually mixed with wood chips. The food waste and wood chips ratio was always 70:30 in wet mass. The tests are detailed as follows:

Trial 1 - The composters were monitored in duplicate. A semi-continuous feed operating system was adopted. The composters were filled within a seven-day frequency. The amount of mixed food waste and wood chips placed inside the composters when they were filled was 
enough to complete them (Table 1). In this trial, manual turning of the mixture was done daily for better aeration.

Trial 2 - On the first day the batch compost was filled with fresh food waste and wood chips from the remaining material in the compost at the end of Trial 1 . The turning frequency was daily during the first week and every two days in the weeks that followed. Table 1 shows the initial characteristics of the mixture during this experiment.

Trial 3 - The batch compost was filled on the first day with fresh food waste, $50 \%$ wood chips and 50\% wood chips from the remaining material in the compost at the end of Trial 2. The turning frequency during the first week was daily and every 7 days thereafter. Table 1 also details the initial characteristics for this mixture.

Table 1. $\mathrm{pH}$, moisture content $(\mathrm{M})$, organic matter $(\mathrm{OM})$, carbon $(\mathrm{C})$, nitrogen $(\mathrm{N})$ and $\mathrm{C} / \mathrm{N}$ ratio $(\mathrm{C} / \mathrm{N})$ from food waste and wood chips used in all the trials.

Food waste

\begin{tabular}{|c|c|c|c|c|c|c|c|c|c|c|c|}
\hline \multicolumn{6}{|c|}{ Trial 1 - Filling 1} & \multicolumn{6}{|c|}{ Trial 1 - Filling 2} \\
\hline $\mathrm{pH}$ & $\mathrm{M}(\%)$ & $\mathrm{OM}(\%)$ & $\mathrm{C}(\%)$ & $\mathrm{N}(\%)$ & $\mathrm{C} / \mathrm{N}$ & $\mathrm{pH}$ & $\mathrm{M}(\%)$ & $\mathrm{OM}(\%)$ & $\mathrm{C}(\%)$ & $\mathrm{N}(\%)$ & $\mathrm{C} / \mathrm{N}$ \\
\hline 5.4 & 87.5 & 71.2 & 28.8 & 1.5 & 19.2 & 5.0 & 87.4 & 78.2 & 31.4 & 2.3 & 13.7 \\
\hline \multicolumn{6}{|c|}{ Trial 1 - Filling 3} & \multicolumn{6}{|c|}{ Trial 1 - Filling 4} \\
\hline $\mathrm{pH}$ & $\mathrm{M}(\%)$ & $\mathrm{OM}(\%)$ & $\mathrm{C}(\%)$ & $\mathrm{N}(\%)$ & $\mathrm{C} / \mathrm{N}$ & $\mathrm{pH}$ & $\mathrm{M}(\%)$ & $\mathrm{OM}(\%)$ & $\mathrm{C}(\%)$ & $\mathrm{N}(\%)$ & $\mathrm{C} / \mathrm{N}$ \\
\hline 5.4 & 85.3 & 74.0 & 31.4 & 1.5 & 20.9 & 5.6 & 90.2 & 84.8 & 38.5 & 2.3 & 16.7 \\
\hline \multicolumn{6}{|c|}{ Trial 2} & \multicolumn{6}{|c|}{ Trial 3} \\
\hline $\mathrm{pH}$ & $\mathrm{M}(\%)$ & $\mathrm{OM}(\%)$ & $\mathrm{C}(\%)$ & $\mathrm{N}(\%)$ & $\mathrm{C} / \mathrm{N}$ & $\mathrm{pH}$ & $\mathrm{M}(\%)$ & $\mathrm{OM}(\%)$ & $\mathrm{C}(\%)$ & $\mathrm{N}(\%)$ & $\mathrm{C} / \mathrm{N}$ \\
\hline 3.6 & 82.6 & 94.7 & 30.7 & 1.4 & 21.9 & 4.9 & 84.1 & 88.1 & 34.4 & 1.0 & 34.4 \\
\hline \multicolumn{12}{|c|}{ Wood chips } \\
\hline \multicolumn{6}{|c|}{ Trial 1 - Filling 1} & \multicolumn{6}{|c|}{ Trial 1 - Filling 2} \\
\hline $\mathrm{pH}$ & $\mathrm{M}(\%)$ & $\mathrm{OM}(\%)$ & $\mathrm{C}(\%)$ & $\mathrm{N}(\%)$ & $\mathrm{C} / \mathrm{N}$ & $\mathrm{pH}$ & $\mathrm{M}(\%)$ & $\mathrm{OM}(\%)$ & $\mathrm{C}(\%)$ & $\mathrm{N}(\%)$ & $\mathrm{C} / \mathrm{N}$ \\
\hline $4.4^{\mathrm{a}}$ & $10.0^{\mathrm{a}}$ & $99.1^{\mathrm{a}}$ & $28.6^{\mathrm{a}}$ & $0.2^{\mathrm{a}}$ & $145.3^{\mathrm{a}}$ & $4.4^{\mathrm{a}}$ & $10.0^{\mathrm{a}}$ & $99.1^{\mathrm{a}}$ & $28.6^{\mathrm{a}}$ & $0.2^{\mathrm{a}}$ & $145.3^{\mathrm{a}}$ \\
\hline \multicolumn{6}{|c|}{ Trial 1 - Filling 3} & \multicolumn{6}{|c|}{ Trial 1 - Filling 4} \\
\hline $\mathrm{pH}$ & $\mathrm{M}(\%)$ & OM (\%) & $\mathrm{C}(\%)$ & $\mathrm{N}(\%)$ & $\mathrm{C} / \mathrm{N}$ & $\mathrm{pH}$ & $\mathrm{M}(\%)$ & $\mathrm{OM}(\%)$ & $\mathrm{C}(\%)$ & $\mathrm{N}(\%)$ & $\mathrm{C} / \mathrm{N}$ \\
\hline $4.4^{\mathrm{a}}$ & $10.0^{\mathrm{a}}$ & $99.1^{\mathrm{a}}$ & $28.6^{\mathrm{a}}$ & $0.2^{\mathrm{a}}$ & $145.3^{\mathrm{a}}$ & $4.4^{\mathrm{a}}$ & $10.0 \mathrm{a}$ & $99.1^{\mathrm{a}}$ & $28.6^{\mathrm{a}}$ & $0.2^{\mathrm{a}}$ & $145.3^{\mathrm{a}}$ \\
\hline \multicolumn{6}{|c|}{ Trial 2} & \multicolumn{6}{|c|}{ Trial 3} \\
\hline $\mathrm{pH}$ & M (\%) & OM (\%) & $\mathrm{C}(\%)$ & $\mathrm{N}(\%)$ & $\mathrm{C} / \mathrm{N}$ & $\mathrm{pH}$ & M (\%) & $\mathrm{OM}(\%)$ & $\mathrm{C}(\%)$ & $\mathrm{N}(\%)$ & $\mathrm{C} / \mathrm{N}$ \\
\hline $67^{c}$ & $42 \partial^{b}$ & $865^{b}$ & $35 \mathrm{gb}$ & $0 a^{b}$ & $386^{\mathrm{b}}$ & $4.4^{\mathrm{a}}$ & $10.0^{\mathrm{a}}$ & $99.1^{\mathrm{a}}$ & $28.6^{\mathrm{a}}$ & $0.2^{\mathrm{a}}$ & $145.3^{\mathrm{a}}$ \\
\hline & & & & & & $6.9^{c}$ & $15.9^{\mathrm{c}}$ & $85.3^{c}$ & $37.1^{\mathrm{c}}$ & $1.4^{\mathrm{c}}$ & $25.8^{c}$ \\
\hline
\end{tabular}

a- New wood chips; b- wood chips from trial 1; c- wood chips from trial 2. 
The flowchart in Figure 2 illustrates the filling of the compost bins with sufficient amounts of mixed food waste and woodchips to complete them, and the turning frequency during the phases of the experiment.

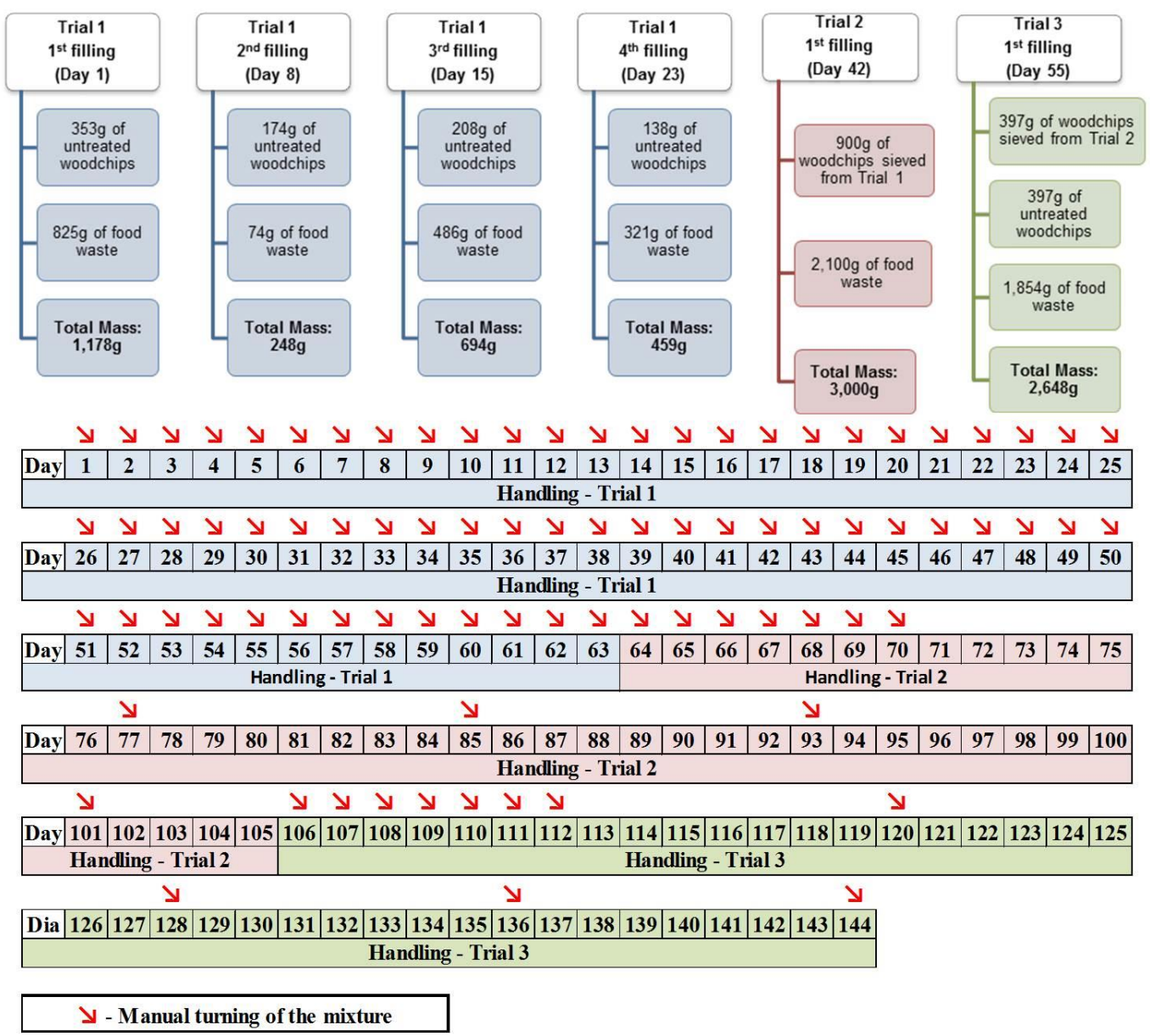

Figure 2. Flowchart illustrating the experimental management.

\subsection{Composting monitoring}

Several parameters were monitored over time: Temperature (T), pH, Moisture (M), Organic Matter (OM), Total Carbon (C) and Total Kjeldahl Nitrogen (N). Temperature was monitored daily, while the other parameters were monitored weekly. Total coliforms and Escherichia coli were only quantified for the last compost trial.

The $\mathrm{pH}$ value was determined with a $\mathrm{pH}$ meter equipped with electrodes using $1 \mathrm{~g}$ of the sample immersed in $50 \mathrm{~mL}$ of $\mathrm{CaCl}_{2}(0.01 \mathrm{M})$ and stirred for 30 minutes. The moisture content and organic matter were analyzed according to the Standard Methods for the Examination of Water and Wastewater (APHA et al., 2012). Total Kjeldahl nitrogen was determined using an adapted methodology of the 4500-Norg B method; $200 \mathrm{mg}$ of the sample was placed in macro kjeldahl flasks containing $1 \mathrm{ml}$ of commercial $\mathrm{H}_{2} \mathrm{O}_{2}, 700 \mathrm{mg}$ of digestion mix (containing $100 \mathrm{~g}$ of $\mathrm{Na}_{2} \mathrm{SO}_{4}, 10 \mathrm{~g}$ of $\mathrm{CuSO}_{4} 5 \mathrm{H}_{2} \mathrm{O}$ and $1 \mathrm{~g}$ of selenium) and $5 \mathrm{ml}$ of concentrated $\mathrm{H}_{2} \mathrm{SO}_{4}$. The digestion was conducted in the Büchi SpeedDigester K-425. After digestion, $50 \mathrm{ml}$ of deionized water and $35 \mathrm{ml}$ of $10 \mathrm{M} \mathrm{NaOH}$ were added to the sample, which was then distilled in $50 \mathrm{ml}$ of boric acid pH 4.65 in distillation unit K-355, Büchi. Total carbon was determined in a high-temperature solids combustion system $\left(1,200^{\circ} \mathrm{C}\right)$ using the multi $\mathrm{N} / \mathrm{C}^{\circledR} 2100$ analyzer from Analytic Jena. Total coliforms and Escherichia coli were quantified by the defined substrate technique using Colilert $^{\circledR}$, IDEXX. 
The compost quality was analyzed by considering the reference limits of the norms adopted by Brazil's Agriculture Ministry for organic fertilizers Class C, which includes raw materials originating from domestic waste.

\section{RESULTS AND DISCUSSION}

The composting process was monitored for 63 days in Trial 1, 42 days in Trial 2 and 39 days in Trial 3, a total of 144 days of operation. In all trials, the temperature of the compost material ranged between $26.7^{\circ} \mathrm{C}$ and $46.2^{\circ} \mathrm{C}$ throughout the process.

The highest temperatures observed were obtained in the first three days after the addition of residue, except for the first filling of Trial 1, when the maximum temperature $\left(30.9^{\circ} \mathrm{C}\right)$ was achieved after only 6 days of operation. The highest temperatures, $46.2^{\circ} \mathrm{C}$ and $44.9^{\circ} \mathrm{C}$, were obtained in Trials 2 and 3, respectively (Figure 3).

- Compost bin 0 Ambient

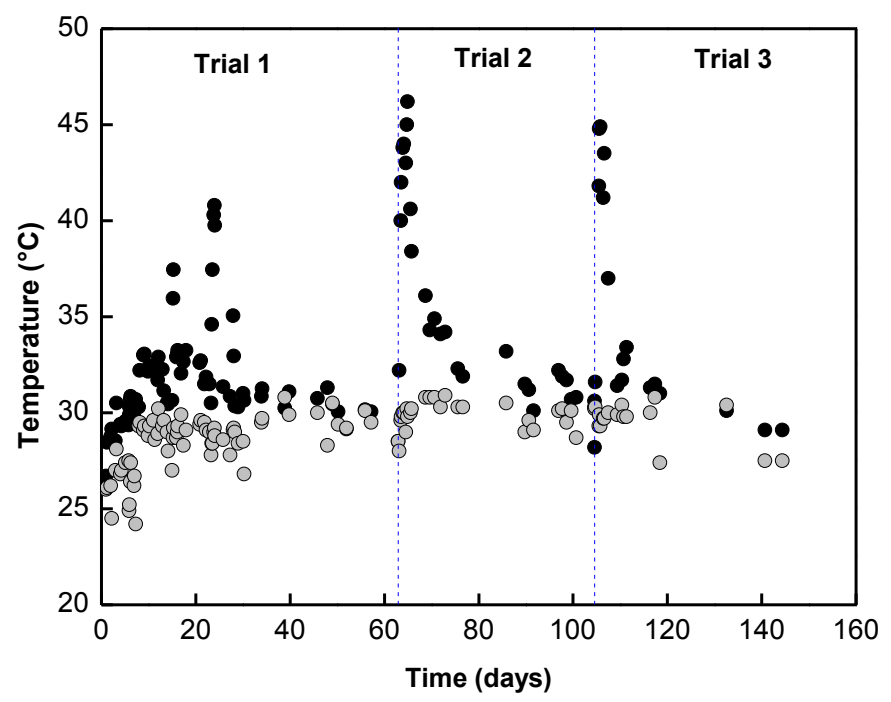

Figure 3. Temperature variation over time in the environment $(\mathrm{O})$ and in the compost bin $(\bullet)$.

According to Ryckeboer et al. (2003), under optimal conditions the composting process can be divided into four phases: an initial mesophilic phase $\left(10^{\circ} \mathrm{C}-42^{\circ} \mathrm{C}\right)$ which can last for hours or days, a thermophilic phase $\left(45^{\circ} \mathrm{C}-75^{\circ} \mathrm{C}\right)$ which can last a few days, weeks or months, a second mesophilic phase and the final maturation and stabilization phase. However, studies on household food waste composting in compact systems found a similar temperature variation pattern as that found in this study, with a thermophilic stage that is non-existent or only lasts a few hours (Colón et al., 2010).

The self-heating during the composting process is determined by the biodegradability and the energy content of the substrate, the availability of moisture, oxygen and the energy conservation model, for example isolation and convective losses (Ryckeboer et al., 2003). An initial high temperature was caused by the decomposition of easily available carbon from putrescible food wastes. The temperature variation below the thermophilic range observed in compact systems is attributed to two major factors: the outside temperature variation and the low thermal insulation of the compost, which is caused by its reduced volume (Colón et al., 2010).

Faverial and Sierra (2014) observed a change of only a few degrees above room temperature $\left(2^{\circ} \mathrm{C}-12^{\circ} \mathrm{C}\right)$ in 400 -litre composters filled twice a week with food waste and garden pruning. The maximum temperature of $43^{\circ} \mathrm{C}$ was always observed 3-4 days after the addition of food waste. Colón et al. (2010) observed a maximum temperature of $65^{\circ} \mathrm{C}$ and an

\section{IPABH}

Rev. Ambient. Água vol. 12 n. 5 Taubaté - Sep. / Oct. 2017 
average temperature of $37.4^{\circ} \mathrm{C}$ in commercial composting of approximately 500 litres filled once a week, also with food waste and garden pruning. Lleó et al. (2013) operated 300-litre composters, initially half-filled with food waste and garden pruning and subsequently filled once a week. The temperature of $55^{\circ} \mathrm{C}$ was observed only at the beginning of the composting process; during the 200 days of operation, both the ambient temperature and the process temperature showed the same pattern, with small peaks (below $40^{\circ} \mathrm{C}$ ) always occurring after the addition of food waste.

Figure 4 graphically shows the temporal behavior of some parameters that will be discussed below.

A

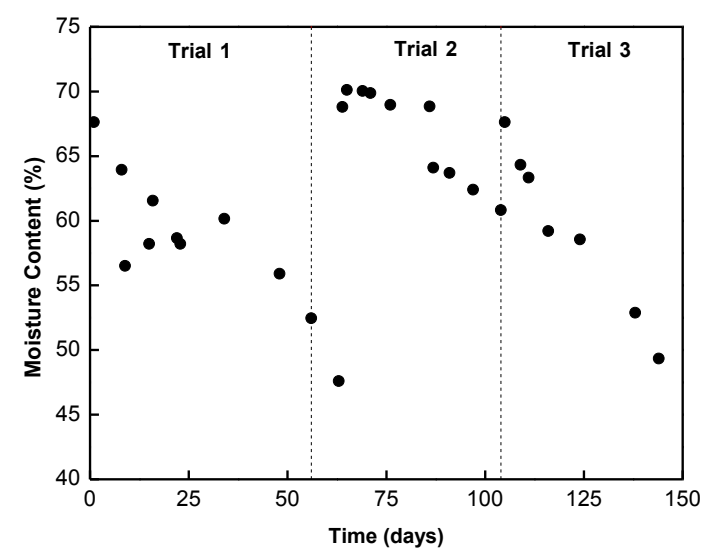

C

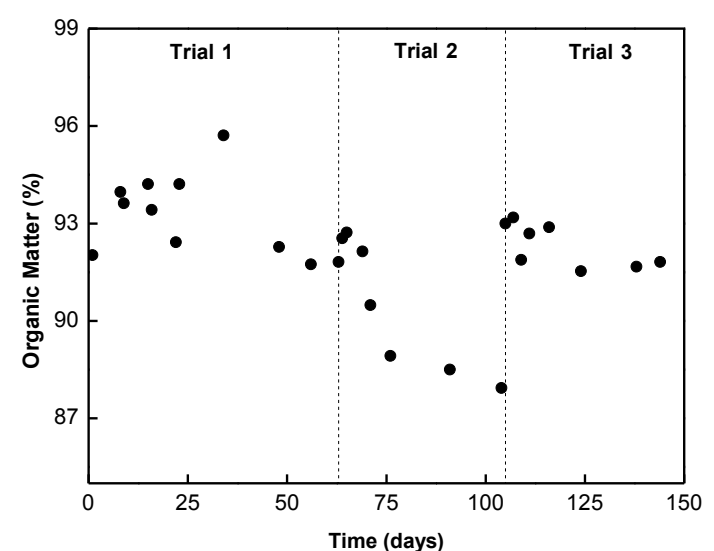

$\mathrm{E}$

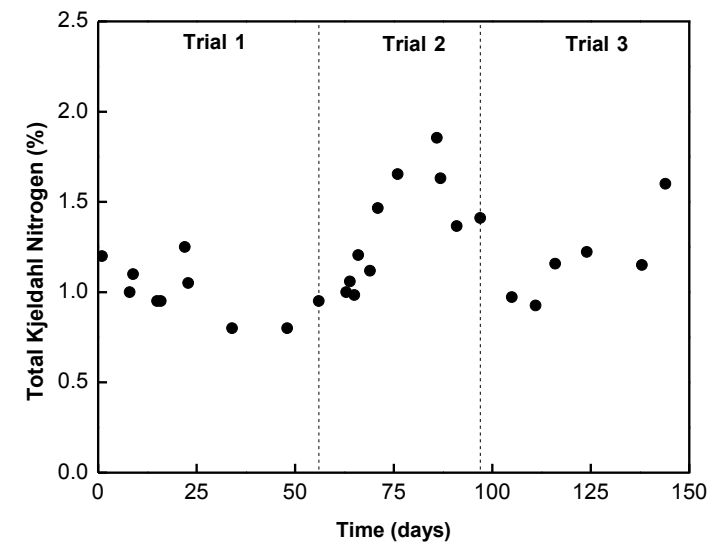

B

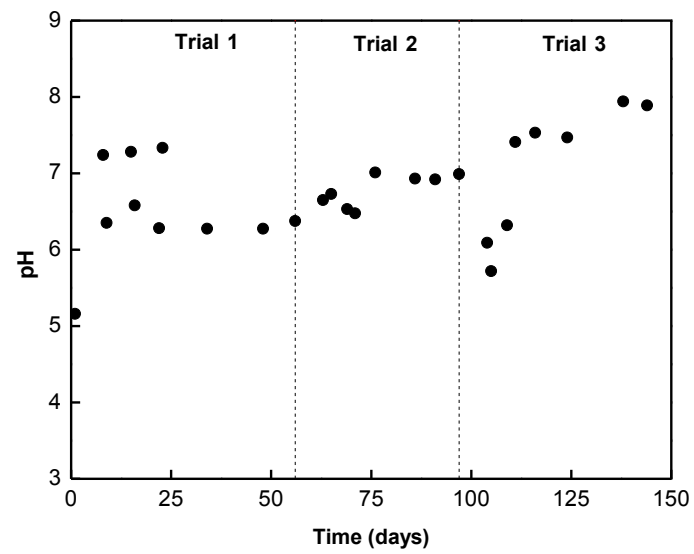

$\mathrm{D}$

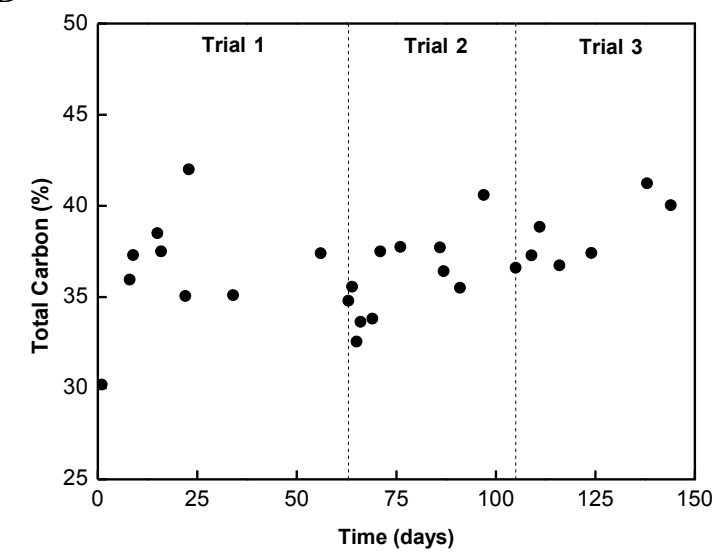

$\mathrm{F}$

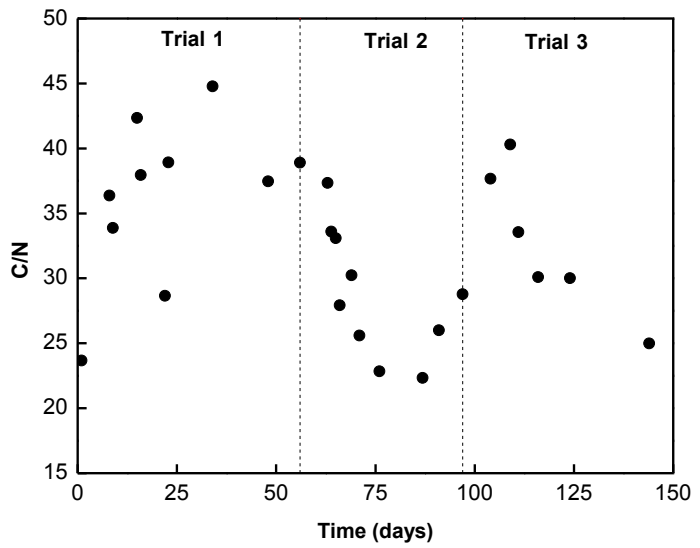

Figure 4. Moisture content (A), pH (B), organic matter (C), total carbon (D), total kjeldahl nitrogen $(\mathrm{E})$ and $\mathrm{C} / \mathrm{N}$ ratio $(\mathrm{F})$ over time during the composting process: - - experimental data. 
The $\mathrm{pH}$ was monitored over time and a significant $\mathrm{pH}$ increase was evident in all trials (Table 2 and Figure 4-B). However, in Trials 1 and 2, the final $\mathrm{pH}$ (6.7 and 6.1, respectively) was below the value ranges commonly found in reduced-volume composting processes. In Trial 3, the final $\mathrm{pH}$ was 7.9. The low $\mathrm{pH}$ values obtained at the start of the experiment can be attributed to organic acids produced from food waste by microorganisms' reactions. Over the first 4 days, the organic acids begin to volatilize as the temperature increases rapidly and organic nitrogen is mineralized by microbial activity, which changes $\mathrm{pH}$ values to $6-7$. In the later stages of composting, the degradation of organic matter is largely complete with low acid production, resulting in a consistently elevated $\mathrm{pH}$ value (Yang et al., 2013).

The moisture content was monitored throughout the process (Figure 4-A); Table 2 shows its initial and final levels in each trial. In all trials, the moisture registered from the composted mass was always less than $70 \%$. No leachate production was recorded in any of the performed trials. In Trials 1 and 3, the final moisture content level was around 50\%. In Trial 2, which was performed with the addition of structural material resulting from the first trial, the final moisture level was close to $60 \%$. This higher percentage is explained by the fact that no new wood chips (responsible for moisture control) were inserted in the process. Nevertheless, the moisture levels are in agreement with those obtained by other authors in experiments with low-volume composters, ranging between 44 and 73\% (Barrena et al., 2014; Ermolaev et al., 2014; Faverial and Sierra, 2014; Quirós et al., 2014; Lleó et al., 2013; Karnchanawong and Suriyanon, 2011).

Table 2. Initial, final and compost $\mathrm{pH}$, moisture content $(\mathrm{M})$, organic matter $(\mathrm{OM})$, carbon $(\mathrm{C})$, nitrogen $(\mathrm{N})$ and $\mathrm{C} / \mathrm{N}$ ratio $(\mathrm{C} / \mathrm{N})$ in all trials.

\begin{tabular}{|c|c|c|c|c|c|c|c|c|c|c|c|c|}
\hline \multirow[b]{2}{*}{ Properties } & \multicolumn{6}{|c|}{ Trial 1 - Filling 1} & \multicolumn{6}{|c|}{ Trial 1 - Filling 2} \\
\hline & $\mathrm{pH}$ & $\mathrm{M}(\%)$ & $\mathrm{OM}(\%)$ & $\mathrm{C}(\%)$ & $\mathrm{N}(\%)$ & $\mathrm{C} / \mathrm{N}$ & $\mathrm{pH}$ & $\mathrm{M}(\%)$ & $\mathrm{OM}(\%)$ & $\mathrm{C}(\%)$ & $\mathrm{N}(\%)$ & $\mathrm{C} / \mathrm{N}$ \\
\hline Initial & 5.2 & 67.6 & 92.0 & 23.7 & 1.2 & 23.7 & 6.4 & 56.5 & 93.6 & 33.9 & 1.1 & 33.9 \\
\hline Final & 7.2 & 63.9 & 93.9 & 36.4 & 1.0 & 36.4 & 7.3 & 58.2 & 94.2 & 42.3 & 1.0 & 42.3 \\
\hline \multirow[t]{2}{*}{ Compost* } & \multicolumn{6}{|c|}{ nd } & \multicolumn{6}{|c|}{ nd } \\
\hline & \multicolumn{6}{|c|}{ Trial 1 - Filling 3} & \multicolumn{6}{|c|}{ Trial 1 - Filling 4} \\
\hline Properties & $\mathrm{pH}$ & $\mathrm{M}(\%)$ & $\mathrm{OM}(\%)$ & $\mathrm{C}(\%)$ & $\mathrm{N}(\%)$ & $\mathrm{C} / \mathrm{N}$ & $\mathrm{pH}$ & M (\%) & $\mathrm{OM}(\%)$ & $\mathrm{C}(\%)$ & $\mathrm{N}(\%)$ & $\mathrm{C} / \mathrm{N}$ \\
\hline Initial & 6.6 & 61.6 & 93.4 & 37.9 & 1.0 & 37.9 & 6.3 & 58.2 & 90.3 & 38.9 & 1.1 & 38.9 \\
\hline Final & 7.3 & 58.7 & 90.1 & 28.6 & 1.3 & 28.6 & 6.7 & 47.6 & 83.9 & 37.4 & 1.0 & 37.4 \\
\hline \multirow[t]{2}{*}{ Compost* } & \multicolumn{6}{|c|}{ nd } & 6.7 & 28.0 & 66.5 & 31.8 & 1.6 & 20.1 \\
\hline & \multicolumn{6}{|c|}{ Trial 2} & \multicolumn{6}{|c|}{ Trial 3} \\
\hline Properties & $\mathrm{pH}$ & $\mathrm{M}(\%)$ & $\mathrm{OM}(\%)$ & $\mathrm{C}(\%)$ & $\mathrm{N}(\%)$ & $\mathrm{C} / \mathrm{N}$ & $\mathrm{pH}$ & M (\%) & $\mathrm{OM}(\%)$ & $\mathrm{C}(\%)$ & $\mathrm{N}(\%)$ & $\mathrm{C} / \mathrm{N}$ \\
\hline Initial & 4.3 & 68.8 & 92.5 & 35.6 & 1.1 & 33.6 & 5.7 & 67.6 & 93.0 & 36.6 & 1.0 & 37.7 \\
\hline Final & 6.1 & 60.8 & 87.9 & 37.1 & 1.8 & 25.8 & 7.9 & 49.3 & 87.8 & 40.0 & 1.6 & 25.0 \\
\hline Compost* & 7.6 & 50.7 & 80.9 & 40.8 & 2.5 & 16.4 & 8.0 & 50.3 & 82.3 & 37.3 & 2.9 & 13.1 \\
\hline
\end{tabular}

* particle size < $0.42 \mathrm{~mm}$; nd - not determined.

Moisture content is the second variable, after temperature, which strongly influences the loss of organic matter and nitrogen (Andersen et al., 2011; Quirós et al., 2014). According to Li et al. (2013), the most favorable moisture content for the biodegradation of different mixtures during composting ranges from $50 \%$ to $70 \%$. Extremely high levels of moisture 
(>70\%) can lead to oxygen depletion, loss of nutrients by leaching and the appearance of anaerobic conditions in which the degradation rate decreases and problems with odor and vector attraction emerge. On the other hand, if the moisture level decreases below a critical level $(<30 \%)$, microbial activity decreases and the microorganisms will enter a dormant state. In addition, extremely low moisture contents may cause operational problems, resulting in poor stability of organic matter (Ryckeboer et al., 2003; Barrena et al., 2014).

The wet and dry mass of the compost mixture was determined at the beginning and end of each trial (Table 3). The initial mass was significantly reduced in all experiments. The reduction in wet mass was 58-69\%, while the reduction in dry mass in Trials 1 and 2 was 51\% and $61 \%$, respectively. The third trial, on the other hand, showed a dry mass reduction of only $37 \%$, explained by the addition of new wood chips. Although they help to control the moisture, wood chips are not readily degraded by microorganisms.

In all trials, there was an estimated reduction of $5-6 \%$ for the initial organic matter content (Figure 4-C). However, the mass balance shown in Table 3 demonstrates higher reductions (37-63\%, dry basis) of organic material during the composting process, also associated with reduced mass and volume.

Table 3. Mass balance of wet weight (WW), dry weight (DW), organic matter (OM), carbon (C) and nitrogen $(\mathrm{N})$ in all trials.

\begin{tabular}{|c|c|c|c|c|c|c|c|c|c|c|}
\hline \multirow{3}{*}{ Parameter } & \multicolumn{5}{|c|}{ Trial 1} & \multicolumn{5}{|c|}{ Trial 1} \\
\hline & \multicolumn{5}{|c|}{ Filling 1} & \multicolumn{5}{|c|}{ Filling 2} \\
\hline & WW & DW & $\mathrm{OM}$ & $\mathrm{C}$ & $\mathrm{N}$ & WW & DW & $\mathrm{OM}$ & $\mathrm{C}$ & $\mathrm{N}$ \\
\hline Initial weight (g) & 1410 & 456 & 420 & 138 & 5 & 1358 & 591 & 553 & 220 & 7 \\
\hline Final weight (g) & 1110 & 400 & 376 & 144 & 4 & 1180 & 494 & 465 & 190 & 5 \\
\hline \multirow[t]{2}{*}{ Reduction (\%) } & 21 & 12 & 10 & 0 & 27 & 13 & 16 & 16 & 14 & 24 \\
\hline & \multicolumn{5}{|c|}{ Trial 1} & \multicolumn{5}{|c|}{ Trial 1} \\
\hline \multirow{2}{*}{ Parameter } & \multicolumn{5}{|c|}{ Filling 3} & \multicolumn{5}{|c|}{ Filling 4} \\
\hline & WW & DW & $\mathrm{OM}$ & $\mathrm{C}$ & $\mathrm{N}$ & WW & $\overline{D W}$ & $\mathrm{OM}$ & $\mathrm{C}$ & $\mathrm{N}$ \\
\hline Initial weight (g) & 1873 & 719 & 672 & 270 & 7 & 1985 & 830 & 749 & 349 & 9 \\
\hline Final weight (g) & 1526 & 631 & 568 & 221 & 8 & 772 & 405 & 340 & 141 & 4 \\
\hline \multirow[t]{2}{*}{ Reduction (\%) } & 19 & 12 & 15 & 18 & 0 & 61 & 51 & 55 & 60 & 56 \\
\hline & \multicolumn{5}{|c|}{ Trial 2} & \multicolumn{5}{|c|}{ Trial 3} \\
\hline Parameter & WW & DW & $\overline{\mathrm{OM}}$ & $\mathrm{C}$ & $\mathrm{N}$ & WW & DW & $\mathrm{OM}$ & $\mathrm{C}$ & $\mathrm{N}$ \\
\hline Initial weight (g) & 3000 & 936 & 866 & 333 & 10 & 2648 & 857 & 797 & 314 & 9 \\
\hline Final weight (g) & 938 & 368 & 323 & 136 & 7 & 1121 & 568 & 499 & 227 & 9 \\
\hline Reduction (\%) & 69 & 61 & 63 & 59 & 36 & 58 & 34 & 37 & 28 & 0 \\
\hline
\end{tabular}

As expected, the carbon levels presented a similar behavior to the organic matter content (Figure 4-D). Although the final carbon levels are greater than the initial levels in almost all trials, with the exception of a few steps in Trial 1, the mass balance shows that there was a carbon reduction of $60 \%$ on a dry basis in the final product of composting in Trials 1 and 2, and a 30\% reduction in Trial 3 (Table 3). The organic substrates and the structural materials used in the composting are largely derived from fruits and vegetables. The carbon compounds serve as an energy source for the maintenance and growth of microorganisms. The yield coefficient, the amount of carbon incorporated into cells per unit of degraded carbon, varies between $10 \%$ and $35 \%$ depending on the energy content of the substrate, on the degrading microorganisms and on environmental conditions (Ryckeboer et al., 2003). 
Table 4 shows that the results obtained in this study are consistent with those found in other papers that have used compact composters. The reduction in the organic matter content found in our work is lower than the reductions found in the papers presented in Table 4, however all the cited studies used pruning waste as a structural material since it shows a higher biodegradability when compared to wood chips.

Table 2 and Figure 4-E show that, with the exception of Trial 1, the nitrogen content (in \%) at the end of the composting process was higher than those originally found in the mixture. The initial $\mathrm{C} / \mathrm{N}$ ratio ranged between 23.7 and 38.9 in Trial 1 , and 33.6 and 37.7 in Trials 2 and 3, respectively (Figure 4-F). At the end of the composting process, there was a reduction of only $4 \%$ in the $\mathrm{C} / \mathrm{N}$ ratio in Trial $1,23 \%$ in Trial 2 , and $34 \%$ in Trial 3. Assuming a microbial grade-point average of $30 \%$ and a mean $\mathrm{C} / \mathrm{N}$ ratio value of 10 , the theoretical value of the $\mathrm{C} / \mathrm{N}$ ratio for an optimum substrate would be 30 . However, in reality, satisfying $\mathrm{C} / \mathrm{N}$ ratios ranging between 25 and 35 have been reported in the literature. During the composting process, the $\mathrm{C} / \mathrm{N}$ ratio decreases significantly because of the carbon loss in the form of $\mathrm{CO}_{2}$ through microbial respiration, while nitrogen is recycled (Ryckeboer et al., 2003). However, the rate of organic nitrogen mineralization is lower than that of organic carbon, causing the $\mathrm{C} / \mathrm{N}$ ratio to decrease during composting (Yang et al., 2013). In our research, despite a reduction during the composting process, the $\mathrm{C} / \mathrm{N}$ ratios found at the end of each trial were higher than those found in the literature (Table 4).

Table 4. Range of some parameters of the final material (particle size $>0.42 \mathrm{~mm}$ ) and compost (particle size $<0.42 \mathrm{~mm}$ ) from Trials 1, 2 and 3. Some literature reference values are given for home composts.

\begin{tabular}{|c|c|c|c|c|c|c|c|}
\hline Composter Volume & $\mathrm{pH}$ & $\begin{array}{c}\mathrm{M} \\
(\%)\end{array}$ & $\begin{array}{l}\mathrm{OM} \\
(\%)\end{array}$ & $\begin{array}{l}\mathrm{C} \\
(\%)\end{array}$ & $\begin{array}{l}\mathrm{N} \\
(\%)\end{array}$ & $\mathrm{C} / \mathrm{N}$ & Reference \\
\hline $300 \mathrm{~L}$ & 9.0 & 50.3 & 75.0 & - & 1.7 & - & Lleó et al. (2013) \\
\hline $400 \mathrm{~L}$ & 7.7 & - & 46.4 & 26.2 & 2.2 & 11.8 & Faverial and Sierra (2014) \\
\hline $300 \mathrm{~L}$ & 8.3 & 44.0 & 49.0 & - & 2.4 & - & Quirós et al. (2014) \\
\hline $230-400 \mathrm{~L}$ & 7.2 & 73.0 & - & - & - & - & Ermolaev et al. (2014) \\
\hline Not mentioned & 7.7 & 44.0 & 57.0 & - & 2.2 & 16.0 & Barrena et al. (2014) \\
\hline $200 \mathrm{~L}$ & $\begin{array}{l}7.1- \\
7.5\end{array}$ & - & - & - & $1.3-1.5$ & $\begin{array}{l}16.0- \\
19.2\end{array}$ & $\begin{array}{l}\text { Karnchanawong and } \\
\text { Suriyanon (2011) }\end{array}$ \\
\hline $10 \mathrm{~L}$ & $\begin{array}{l}6.1- \\
7.9\end{array}$ & $\begin{array}{l}47.6- \\
60.8\end{array}$ & $\begin{array}{l}83.9- \\
87.9\end{array}$ & $\begin{array}{l}28.6- \\
40.0\end{array}$ & $1.0-1.8$ & $\begin{array}{r}25.0- \\
37.4\end{array}$ & Our study ${ }^{a}$ \\
\hline $10 \mathrm{~L}$ & $\begin{array}{l}6.7- \\
8.0\end{array}$ & $\begin{array}{l}28.0- \\
50.7\end{array}$ & $\begin{array}{l}66.5- \\
82.3\end{array}$ & $\begin{array}{c}31.8- \\
40.8\end{array}$ & 1.6-2.9 & $\begin{array}{l}13.1- \\
20.1\end{array}$ & Our study ${ }^{b}$ \\
\hline $\begin{array}{l}\text { Brazilian } \\
\text { Regulation* }\end{array}$ & $\begin{array}{l}6.5 \\
(\mathrm{~min})\end{array}$ & $\begin{array}{c}50.0 \\
(\max .)\end{array}$ & & $\begin{array}{l}15.0 \\
(\min .)\end{array}$ & $\begin{array}{c}0.5 \\
\text { (min.) }\end{array}$ & $\begin{array}{c}20.0 \\
(\max .)\end{array}$ & Brasil (2006) \\
\hline
\end{tabular}

a- particle size $>0.42 \mathrm{~mm}$; b- Particle size $<0.42 \mathrm{~mm}$.

* Organic fertilizers class $\mathrm{C}$, which includes raw materials originating from domestic waste.

Source: Lleó et al. (2013); Faverial and Sierra (2014); Quirós et al. (2014); Ermolaev et al. (2014); Barrena et al. (2014); Karnchanawong and Suriyanon (2011); Brasil (2006).

After each test, the final compost was sieved and particles smaller than $0.42 \mathrm{~mm}$ were analyzed as the final compound process. Low-level production of compost of about $2 \%$ of the final dry mass was observed in Trials 1 and 2, while in Trial 3,1\% was obtained. The pH value, the carbon and nitrogen contents and the $\mathrm{C} / \mathrm{N}$ rate were in accordance with the values recommended by Brazilian legislation (Table 4). In Trials 2 and 3, moisture was slightly higher than the allowed value.

By the reference limits of the norms adopted by Brazil's Agriculture Ministry for Class C organic fertilizers, which includes raw materials originating from domestic waste, thermo 
tolerant coliforms must be below $10^{3} \mathrm{MPN}^{-}{ }^{-}$total solids. The quantification of $E$. coli indicated the presence of 4.1 MPN g-1 total solids in the compost of Trial 1 and $250 \mathrm{MPN} \mathrm{g}^{-1}$ total solids in the compost of Trial 3. Only the compost resulting from Trial 2 did not match the standards, which showed $1900 \mathrm{MPN} \mathrm{g}^{-1}$ total solids. As the temperatures throughout the experiment did not reach the thermophilic phase and were suitable for the growth of microorganisms, sanitization of the material (destruction of viable pathogens and weed seeds) cannot be ensured. However, the relatively long residence of the waste in the composter allows for these pathogenic microorganisms to decay naturally (Colón et al., 2010).

\section{CONCLUSION}

This study has demonstrated that: (1) The stabilization of food waste is feasible in simple- and small composters filled with food preparation waste and wood chips as a structural material. Even if the compound did not always suit agricultural use, its low production created beneficial waste-mass reduction; (2) In situations where there is no pruning waste production, wood chips can be used and reused in subsequent composting cycles without compromising process efficiency; (3) The daily manual turning of the mixture in the first week after the addition of the food waste is effective in terms of maintaining the aerobic process and preventing the formation of leachate; (4) The possibilities of the process and the small-scale production of the compound can be useful in places where space is limited; (5) Finally, improvements are needed so that thermophilic temperatures can be reached in order to guarantee the microbiologic quality of the compost. However, the adoption of longer composting periods may allow the natural decay of pathogenic microorganisms.

\section{ACKNOWLEDGEMENTS}

This study was funded by resources of FINEP (550181/2012-1) and FAPESB (PES0037/2013 and 0020/2013).

\section{REFERENCES}

AMERICAN PUBLIC HEALTH ASSOCIATION APHA; AMERICAN WATER WORKS ASSOCIATION, AWWA; WATER ENVIRONMENT FEDERATIONWEF. Standard Methods for the Examination of Water and Wastewater. 22 ${ }^{\text {nd }}$ ed. Washington, 2012.

ANDERSEN, J.; BOLDRIN, A.; CHRISTENSEN, T.; SCHEUTZ, C. Mass balances and life cycle inventory of home composting of organic waste. Waste Management, v. 31, n. 910, p. 1934-1942, 2011. http://dx.doi.org/10.1016/j.wasman.2011.05.004

BARRENA, R.; FONT, X.; GABARRELL, X. SÁNCHEZ, A. Home composting versus industrial composting: Influence of composting system on compost quality with focus on compost stability. Waste Management, v. 34, n. 7, p. 1109-1116, 2014. http://dx.doi.org/10.1016/j.wasman.2014.02.008

BRASIL. Ministério da Agricultura, Pecuária e Abastecimento. Instrução Normativa ${ }^{\circ}{ }^{25}$, de 23 de maio de 2006. Estabelece os critérios mínimos a serem observados para a determinação do Valor de Cultivo e Uso - VCU de feijão e os respectivos formulários para inscrição de cultivares no Registro Nacional de Cultivares. Diário Oficial [da] União, Brasília, 19 jun. 2006. 
BRASIL. Casa Civil. Lei ${ }^{\circ}$ 12.305, de 2 de agosto de 2010. Institui a Política Nacional de Resíduos Sólidos; altera a Lei no 9.605, de 12 de fevereiro de 1998; e dá outras providências. Diário Oficial [da] União, Brasília, 03 ago. 2010.

BRASIL. Ministério do Meio Ambiente. Plano Nacional de Resíduos Sólidos. Brasília, 2012.

CHANG, J. I.; TSAI, J. J.; WU, K. H. Composting of vegetable waste. Waste Management and Research, v. 24, p. 354-362, 2006. http://dx.doi.org/10.1177/0734242X06065727

COLÓN, J.; MARTÍNEZ-BLANCO, J.; GABARRELL, X.; ARTOLA, A.; SÁNCHEZ, A.; RIERADEVALL, J. et al. Environmental assessment of home composting. Resources, Conservation and Recycling, v. 54, n. 11, p. 893-904, 2010.

http://dx.doi.org/10.1016/j.resconrec.2010.01.008

ERMOLAEV, E.; SUNDBERG, C.; PELL, M.; JÖNSSON, H. Greenhouse gas emissions from home composting in practice. Bioresource Technology, v. 151, p. 174-182, 2014. http://dx.doi.org/10.1016/j.biortech.2013.10.049

FAVERIAL, J.; SIERRA, J. Home composting of household biodegradable wastes under the tropical conditions of Guadeloupe (French Antilles). Journal of Cleaner Production, v. 83, p. 238-244, 2014. http://dx.doi.org/10.1016/j.jclepro.2014.07.068.

KARNCHANAWONG, S.; SURIYANON, N. Household organic waste composting using bins with different types of passive aeration. Resources, Conservation and Recycling, v. 55, n. 5, p. 548-553, 2011. https://doi.org/10.1016/j.resconrec.2011.01.006

LI, Z.; LU, H.; REN, L.; HE, L. Experimental and modelling approaches for food waste composting. Chemosphere, v. 93, n. 7, p. 1247-1257, 2013.

http://dx.doi.org/10.1016/j.resconrec.2011.01.006

LLEÓ, T.; ALBACETE, E.; BARRENA, R.; FONT, X.; ARTOLA, A.; SÁNCHEZ, A. Home and vermicomposting as sustainable options for biowaste management. Journal of Cleaner Production, v. 47, p. 70-76, 2013.

http://dx.doi.org/10.1016/j.jclepro.2012.08.011

QUIRÓS, R.; VILlALBA, G.; MUÑOZ, P.; COLÓN, J.; FONT, X.; GABARRELL, X. Environmental assessment of two home composts with high and low gaseous emissions of the composting process. Resources, Conservation and Recycling, v. 90, p. 9-20, 2014. http://dx.doi.org/10.1016/j.resconrec.2014.05.008

RYCKEBOER, J.; MERGAERT, J.; VAES, K.; KLAMMER, S.; CLERCQ, D. D.; COOSEMANS, J. et al. A survey of bacteria and fungi occurring during composting and self-heating processes. Annals of Microbiology, v. 53, n. 4, p. 349-410, 2003.

YANG, F.; LI, G. X.; YANG, Q. Y.; LUO, W. H. Effect of bulking agents on maturity and gaseous emissions during kitchen waste composting. Chemosphere, v. 93, n. 7, p. 1393-1399, 2013. http://dx.doi.org/10.1016/j.chemosphere.2013.07.002 